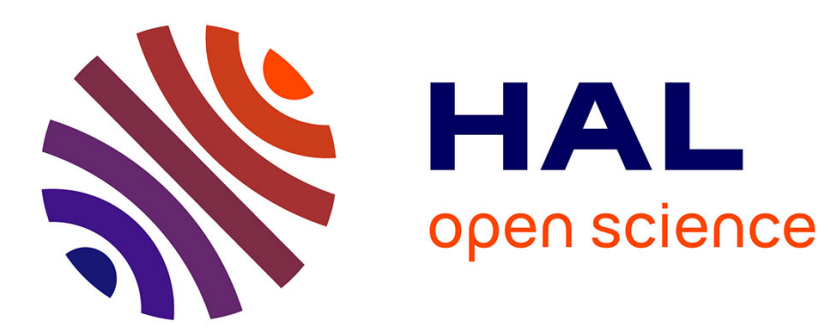

\title{
Positive Futures? The impact of HIV infection on achieving health, wealth and future planning 'AIDS IMPACT SPECIAL ISSUE'
}

\author{
Richard Harding, Tim Molloy
}

\section{- To cite this version:}

Richard Harding, Tim Molloy. Positive Futures? The impact of HIV infection on achieving health, wealth and future planning 'AIDS IMPACT SPECIAL ISSUE'. AIDS Care, 2008, 20 (05), pp.565-570. 10.1080/09540120701867222 . hal-00513458

\section{HAL Id: hal-00513458 \\ https://hal.science/hal-00513458}

Submitted on 1 Sep 2010

HAL is a multi-disciplinary open access archive for the deposit and dissemination of scientific research documents, whether they are published or not. The documents may come from teaching and research institutions in France or abroad, or from public or private research centers.
L'archive ouverte pluridisciplinaire HAL, est destinée au dépôt et à la diffusion de documents scientifiques de niveau recherche, publiés ou non, émanant des établissements d'enseignement et de recherche français ou étrangers, des laboratoires publics ou privés. 

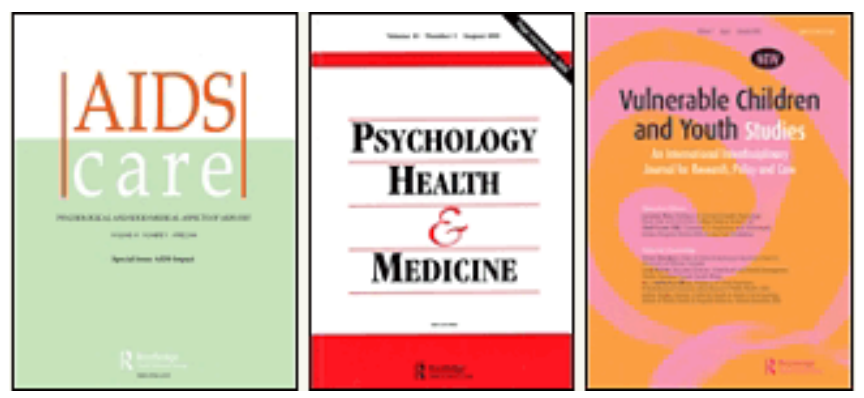

Positive Futures? The impact of HIV infection on achieving health, wealth and future planning 'AIDS IMPACT SPECIAL ISSUE'

\begin{tabular}{|r|l|}
\hline Journal: & $\begin{array}{l}\text { AIDS Care - Psychology, Health \& Medicine - Vulnerable Children } \\
\text { and Youth Studies }\end{array}$ \\
\hline Manuscript ID: & AC-2007-09-0492.R1 \\
\hline Journal Selection: & AIDS Care \\
\hline Keywords: & HIV, Gay Men, Life Expectancy, Mental Health, Symptoms \\
\hline \multicolumn{2}{|c}{} \\
\hline
\end{tabular}

\section{s ScholarONE \\ Manuscript Central}


Positive Futures? The impact of HIV infection on achieving health, wealth and future planning

Word count: 2760

Keywords: HIV, gay men, life expectancy, mental health, employment, symptoms 


\section{Abstract}

Although HIV is now cast as a chronic condition with favourable clinical outcomes under new treatments, it is unclear how living with HIV affects expectations and planning for the future. This mixed methods study aimed to investigate UK gay men's expectations of their own future when living with HIV, and to identify the heath and social interventions required to enhance roles, participation and personal fulfilment. A preliminary focus group identified relevant domains of enquiry for a subsequent online cross sectional survey.

347 gay men living in the UK with HIV participated in the survey, and $56.6 \%$ were currently on treatment. However, high 7-day prevalence of psychological and physical symptoms were identified (42.6 in pain, $80.2 \%$ worrying). $57.8 \%$ perceived reduced career options due to their infection, and $71.8 \%$ reduced life expectancy. Being on treatment was not significantly associated with perceived life expectancy. Coded open-ended survey data identified 8 principle themes related to goal planning and attainment. The integrated open and closed data items offer an understanding of barriers and challenges that focus on poor mental health due to clinical inattention, discrimination and stigma, poor career and job opportunities due to benefit and workplace inflexibility and lack of understanding, a lack of personal goals and associated skills deficit related to confidence and self esteem. Gay men living with HIV require an integrated holistic approach to wellbeing that incorporates clinical, social and individual intervention in order to lead productive lives with maximum benefit from treatment gains. 


\section{Background}

HIV infection is now cast as a chronic condition (Chesney et al., 2003) with life expectancy approaching normal in the era of treatment (Lohse et al., 2007). The advances in medical management of viral replication have been accompanied by policy and service shifts that reflect expectations that people living with HIV may lead emotionally and economically productive lives. However, evidence suggests that even with access to effective treatments, people with HIV continue to experience a significant physical and psychological symptom burden (Harding et al., 2006). Under-recognition of symptom prevalence and burden is common. Clinicians in outpatient settings detect only around one third of the problems reported by their patients (Justice et al., 2001).

It is unclear whether people living with HIV share the view of an expected "normal" future, and what they require to achieve a future and quality of life that is appropriate for them. Within the UK, around $85 \%$ of transmissions are between men who have sex with men (Elford et al., 2004). One of the aims of the UK national HIV prevention strategy is that "Men can envisage a future for themselves and means to achieve it [Aim 1.7]" (Hickson et al., 2000).

This study aimed to investigate UK gay men's expectations of their own future when living with HIV, and to identify the heath and social interventions required to enhance roles, participation and personal fulfilment.

\section{Methods}




\section{Setting}

The study was conducted in a community-based volunteer-led organisation aiming to promote gay men's health in London, UK. Actions are planned and executed by volunteers, and are designed to meet the aims and objectives of "Making It Count", the UK's Government-endorsed national collaborative planning framework for reducing HIV incidence among gay men (Hickson et al., 2000).

\section{Design}

The study protocol utilised a sequential mixed methods design, with an initial qualitative phase informing the items for a subsequent online cross-sectional survey.

\section{Procedure}

Phase 1

For the first phase, gay men living with HIV Infection were recruited to a focus group from community groups through email lists, flyers and posters. From those who expressed an interest in attending, a purposive sampling frame was applied to identify a diverse sample with respect to age, ethnicity, time since diagnosis and employment status. Exclusion criteria were men who could not participate in the focus group using spoken English and men with a diagnosis established in the preceding 6 months. The focus group attendees responded to a semi-structured interview schedule, and the discussion was tape recorded following written consent from participants. 
Analysis

The recording was transcribed verbatim, and subjected to line by line independent coding by both authors, and principle codes then compared between the two resulting content analysis coding frames. The integrated codes were then reviewed to inform the items of the second phase.

\section{Phase 2}

For the second phase, an online questionnaire for UK gay men living with HIV was designed and advertised through direct banner links from gay websites, through email lists of gay groups and through flyers. Gay men were invited to complete the survey online with the aim of "looking at the outlook on life and future plans of gay men with HIV" to inform health promotion intervention development. The recruitment methods and questionnaire content were piloted among 5 invited men. Following refinement and recruitment of the final sample, collated data were downloaded from the website into Excel and cleaned. Cases were retained in the final sample for analysis if they were men who had sex with men, with an HIV diagnosis, currently resident in the UK, and had completed $90 \%$ of the questionnaire items.

The survey utilised a number of closed and open-ended sections sections. In addition to items describing demographic and clinical data, items addressed perceived life expectancy and career opportunities, and what respondents perceived was needed to achieve personal goals for the future. The standardised Memorial Symptom Assessment Schedule Short Form (MSASSF) was included, (Chang et al., 2000) (Vogl et al., 1999; Breitbart et al., 1996) a well-validated multidimensional symptom assessment instrument capturing 7-day prevalence and burden of 26 physical symptoms and 4 
psychological symptoms. After identifying symptoms that have been experienced during the preceding week, respondents score each according to the level of discomfort experienced (not at all, a little, somewhat, quite a bit, very much). Subscale indices of global distress, physical symptom distress, and psychological distress are calculated from the burden ratings. Participants scored their belief that HIV had led to them having a reduced life expectancy on a range of 0 (not at all) to 10 (very much so).

Analysis

The sample was first described using descriptive statistics. In a regression model with score on belief in reduced life expectancy as the dependent variable, independent variables with a p value of 0.25 or less (Altman, 1991) were entered stepwise into the multivariate model.

Open ended questions were extracted from the database and analysed using content analysis and organised into agreed key themes (Garcia et al., 2004).

\section{Results}

Phase 1: Focus Group

Nine men participated. Year of diagnosis ranged from 1985-2004. Six were Caucasian, one Middle Eastern, one African Indian and one Black AfricanCaribbean. The mean age was 39.7 years, and 7 were currently on treatment. A number of dominant themes emerged from the data. These codes are summarised as follows, and there was a high level of interaction between these codes, i.e. they combined to have similar and compounding impact: 
uncertainty; living with a long-term diagnosis; being "trapped" on welfare benefits; lack of self confidence; uncertainty; holding self back from doing things and from personally developing; establishing relationships, disclosure, fear of infecting partners; physical symptoms and mental health. Each of these were described as having had a having a major impact on the outlook, role and functioning of the interviewed men and as essential areas to be addressed to enable them to adopt or continue productive and participative roles.

\section{Phase 2: online survey}

\section{Sample characteristics}

Three hundred and forty-seven men completed the survey, and just under half (45.2\%) were resident in London (missing $n=3$ ). Their mean age was 37.5 years (S.D. $=8.3$ years, minimum $=18$, maximum $=76$, missing $n=1$ ). The year of diagnosis was as follows: $2001-2004 n=167$ (48.1\%); 1996-2000 $n=104$ (30.0\%), 1991-1995 n=50 (14.5\%); and before $1991 \mathrm{n}=30$ (8.6\%) (missing $\mathrm{n}=2$ ). Welfare payments as a result of their HIV diagnosis were being received by 128 men (36.1\%). Among these receiving welfare, the majority $(n=84$, $65.6 \%)$ had concerns that ceasing their welfare benefits deterred them from seeking paid employment.

Their most recent CD4 count was a mean of 459 cells $\times 10^{6} / \mathrm{l}$ (median=426, S.D. $=218, \min =30, \max =1500$, missing $n=5)$, and $208(59.9 \%)$ had a detectable viral load. These 208 men had a mean 54,807 copies per $\mathrm{mm}^{3}$ blood (S.D. $=96,434$, minimum $=54$, maximum $=500,000$, missing $n=18) .210$ men $(56.6 \%)$ were currently receiving HAART (missing $n=8$ ). 
Physical and psychological symptoms

The prevalence and burden of symptoms is described in Table 1. It is notable that all four psychological symptoms had a 7-day prevalence of around $70 \%$ and above, and that six physical symptoms had a prevalence of above $50 \%$.

\section{INSERT TABLE 1 HERE}

Perceived career options and life expectancy

The majority of respondents reported a belief that, due to their HIV infection, they had reduced career options $(n=204,57.8 \%)$ and that they had a reduced life expectancy $(n=252,71.8 \%)$. In multivariate analysis with belief in reduced life expectancy as the dependent variable, no significant association was found with time since diagnosis, physical symptom burden, and being on treatment. However, significant associations were found for older age (associated with lower belief in reduced life expectancy, $b=-0.150, p=0.017$ ), and psychological distress burden (higher burden associated with a higher score on belief in shortened life expectancy, $b=0.172, p=0.016)$.

What is needed to achieve your goals for the future?

Open ended data codes to the three questions "what do you need in order to achieve your goals for the future?", "What should an intervention for positive gay men address to help them achieve their goals?" and "what haven't we addressed?" were compared and the principle codes were integrated. In total 517 open-ended response units of texts were coded into the following themes. 
1) Better clinical care/medications; the principle view of respondents was that HIV medicine did not take adequate account of ,or respond appropriately to, mental health needs and side effects of medication. They wanted: "Less ignorance more understanding from the HIV doctors. i.e. side effects and mental illness"

"more support for my mental/emotional wellbeing from my Doctor" "the ability to take medication without gagging or throwing up", and "mental health support".

2) Maintenance of integrated general health; an holistic approach was described by respondents, that advocated a personal approach to maintaining a positive outlook that involves mind and body to influence life achievements. They needed:

"More energy!" "positive outlook"

"I need to stay well. IIIness=worse depression"

"I need to be healthy in order to have ANY future with our without goals, that's my concern".

3) Support services and lessening of discrimination; in addition to describing a need for better clinical responses, men identified a lack of support from within both the gay community and wider society, compounding a lack of support and perceived discrimination. This included:

"Support, trust, love, confidence" "advice and where to find it" "Support and love for want of a better word" "Courage to find out more about HIV as I fear what is ahead of me" 
"regain more working, living and social life", and

"More understanding about HIV In the gay community" "exile from the gay scene".

4) Intimate relationships; a common reported view was that while an intimate relationship would help greatly, an HIV diagnosis made this very difficult. Respondents expressed the need for:

"A sympathetic partner who realises that being the partner of a HIV+ man does not mean you will also become HIV+", or "someone to share my life with" "no stigma for a future partner".

5) Employment; although men living with HIV described a desire to re-enter, or progress within, the employment market, a number of obstacles were identified related to both available training and employer attitudes, including: "raised awareness of issues involved in living and working with HIV without the need for disclosing status" "laws against homophobic "work experience outside the HIV field" and "career advice (not bloody computer training or volunteering)".

6) Financial security; issues related to financial security appeared more pertinent to longer-term diagnosed men, although the data suggest a significant number of men unable to move from welfare payments into paid employment. Respondents highlighted the need for: "more flexibility with benefits" "Am living in the benefits trap!" and "assurances about the ability to maintain an income if I return to work" 
"at least a basic income to be able to cope with the 'inevitable' collapse" "when I was diagnosed I was told that I would be lucky to live over 5 to 10 years- I therefore did not pursue a career as hard as I would have done before and have never made financial provision for later life".

7) Personal fulfilment; although health and social services may aim to assist gay men living with HIV in personal goal planning and financial independent, a core of men were living without hope. The following quotes exemplify respondents" hopelessness:

"I no longer have any goals"

"A way to plan for the future" "stopped all plans for a future when I didn't have one other than short-term when diagnosed" "I will push myself ever harder now even though it may kill me".

8) Personal skills; concrete recommendations for achieving goals and change were centred on mental health and confidence building in addition to advice services. Respondents' needs included:

"I need to rebuild my confidence and self esteem" "need to find a way mental structure to move forward in every area of life" "not think negative because of my HIV status" "no motivation at the moment" "not to feel so ashamed" "positive successful role models- I have real trouble believing in myself any more" "need to get more advice about moving on with my life". 


\section{INSERT FIGURE 1 HERE}

\section{Discussion}

The data clearly demonstrate that UK gay men living with HIV anticipate shortened life expectancy, and that a number of highly prevalent symptoms such as depression, pain and diarrhoea are very debilitating. In the era of treatment, although clinical expectations have improved, our data in the present and previous report demonstrate that being on treatment is not associated with an expectation of normal life expectancy and that treatment is associated with worse physical symptom burden (Harding et al., 2006). Indeed, the prevalence of symptoms in this study is similar to samples of patients living with far advanced malignant disease (Solano et al., 2006), and can be effectively managed (Harding et al., 2005). There are undoubted advantages in commencing treatment, but our sample have described a striking lack of focus on side effects and mental health within their clinical care. Lack of attention to these components of a good quality of life may, sadly, detract from the virological benefits gained from treatment, when burdensome problems persist undetected and poorly managed.

Appropriate responses appear to be multifaceted. These involve clinical attention to symptoms and mental health, individual skills building to develop personal goals and aspiration, welfare systems that enable safe transition into paid employment, and gay community and wider public education to reduce the harmful effects of stigma and discrimination. The needs of long term survivors appear to be greater, with personal challenges more entrenched. 
There are a number of limitations to our study. Firstly, the focus group that informed the survey was relatively small, although it is noteworthy that those emergent themes were confirmed in the larger survey. Second, online survey designs cannot calculate response rates, and the cross-sectional nature of the data cannot identify causal relationships. Lastly, it is possible that online sampling introduces a number of sample biases. However, a study comparing samples of UK gay men using online and community sampling methods found that the men with diagnosed HIV disease differed from the community samples on only two out of 11 demographic and behavioural variables (Elford et al., 2004).

Our data strongly suggest a need for clinical, social and health promotion services to respond to the needs of gay men living with HIV to develop and achieve their goals in response to greater life expectancy. Failure to do so may lead to further discrimination and disadvantage as these men age and are forced into greater poverty.

\section{Acknowledgements}

We are grateful to those agencies who helped to recruit, to Positive Campaigns Group at GMFA who assisted in drafting the questionnaires and commented on data, to the volunteers who assisted in data management, and to the gay men who participated. We thank Emma Camplejohn for her assistance in preparing this manuscript. 


\section{Reference List}

Altman, D. G. (1991). Practical Statistics for Medical Research. London: Chapman and Hall.

Breitbart, W., McDonald, M. V., Rosenfeld, B., Passik, S. D., Hewitt, D., Thaler, H. et al. (1996). Pain in ambulatory AIDS patients. I: Pain characteristics and medical correlates. Pain, Vol 68, 315-321.

Chang, V. T., Hwang, S. S., Feurerman, M., Kasimis, B. S., \& Thaler, H. T. (2000). The Memorial Symptom Assessment Scale Short Form (MSAS-SF). Cancer, 89, 1162-1171.

Chesney, M. A., Chambers, D. B., Taylor, J. M., Johnson, L. M., \& Folkman, S. (2003). Coping effectiveness training for men living with HIV: results from a randomized clinical trial testing a group-based intervention. Psychosomatic Medicine, 65, 1038-1046.

Elford, J., Bolding, G., Davis, M., Sherr, L., \& Hart, G. (2004). Web-based behavioural surveillance among gay men who have sex with men: a comparison of online and offline samples in London. Journal of Acquired Immune Deficiency Syndromes, 35, 421-426.

Garcia, J., Evans, J., \& Reshaw, M. (2004). "ls there anything else you would like to tell us" - methodological issues in the use of free-text comments from postal surveys. Quality and Quantity, 38, 113-125. 
Harding, R., Karus, D., Easterbrook, P., Raveis, V. H., Higginson, I. J., \& Marconi, K. (2005). Does palliative care improve outcomes for patients with HIV/AIDS? A systematic review of the evidence. Sexually Transmitted Infections, 81, 5-14.

Harding, R., Molloy, T., Easterbrook, P., Frame, K., \& Higginson, I. J. (2006). Is antiretroviral therapy associated with symptom prevalence and burden? International Journal of STD \& AIDS, 17, 400-405.

Hickson, F., Nutland, W., Doyle, T., Burbridge, N., Burnell, C., Cadette, M. et al. (2000). Making it Count. http://www.sigmaresearch.org.uk/downloads/report00e.pdf [On-line].

Justice, A. C., Chang, C. H., Rabeneck, L., \& Zackin, R. (2001). Clinical importance of provider-reported HIV symptoms compared with patientreport. Medical Care, 39, 397-408.

Lohse, N., Hansen, A. B., Pedersen, G., Kronborg, G., Gerstoft, J., Sorensen, H. T. et al. (2007). Survival of persons with and without HIV infection in Denmark, 1995-2005. Annals of Internal Medicine, 146, 87-95.

Solano, J. P., Gomes, B., \& Higginson, I. J. (2006). A comparison of symptom prevalence in far advanced cancer, AIDS, heart disease, chronic obstructive pulmonary disease and renal disease. Journal of Pain \& Symptom Management, 31, 58-69.

Vogl, D., Rosenfield, B., Breitbart, W., Thaler, H., Passik, S., McDonald, M. et al. (1999). Symptom prevalence, characteristics and distress in AIDS outpatients. Journal of Pain and Symptom Management, 18, 253-262. 
Table 1: 7-day prevalence of physical and psychological symptoms $(n=347)$

\begin{tabular}{|c|c|c|c|c|c|c|c|}
\hline & \multicolumn{7}{|c|}{ Symptom prevalence } \\
\hline Symptom & Prevalence & $\begin{array}{l}\text { Yes had- } \\
\text { not } \\
\text { bothered }\end{array}$ & $\begin{array}{l}\text { Yes had, } \\
\text { bothered } \\
\text { a little }\end{array}$ & $\begin{array}{l}\text { Yes had } \\
\text { bothered } \\
\text { somewhat }\end{array}$ & $\begin{array}{l}\text { Yes had } \\
\text { bothered } \\
\text { quite a bit } \\
\end{array}$ & $\begin{array}{l}\text { Yes had } \\
\text { bothered } \\
\text { very much }\end{array}$ & Missing \\
\hline $\begin{array}{l}\text { Physical } \\
\text { symptoms }\end{array}$ & & & & & & & \\
\hline $\begin{array}{l}\text { Lack of } \\
\text { energy }\end{array}$ & $71.8 \%$ & $\begin{array}{l}32 \\
(9.1 \%)\end{array}$ & $\begin{array}{l}54 \\
(15.3 \%)\end{array}$ & $\begin{array}{l}65 \\
(18.4 \%)\end{array}$ & $\begin{array}{l}57 \\
(16.1 \%)\end{array}$ & $\begin{array}{l}47 \\
(3.2 \%)\end{array}$ & 2 \\
\hline $\begin{array}{l}\text { Difficulty } \\
\text { sleeping }\end{array}$ & $58.6 \%$ & $\begin{array}{l}28 \\
(8 \%)\end{array}$ & $\begin{array}{l}46 \\
(13.1 \%)\end{array}$ & $\begin{array}{l}38 \\
(10.8 \%)\end{array}$ & $\begin{array}{l}44 \\
(12.5 \%)\end{array}$ & $\begin{array}{l}52 \\
(14.8 \%)\end{array}$ & 3 \\
\hline $\begin{array}{l}\text { Difficulty } \\
\text { concentrating }\end{array}$ & $54.9 \%$ & $\begin{array}{l}21 \\
(5.9 \%)\end{array}$ & $\begin{array}{l}65 \\
(18.3 \%)\end{array}$ & $\begin{array}{l}58 \\
(16.3 \%)\end{array}$ & $\begin{array}{l}31 \\
(8.7 \%)\end{array}$ & $\begin{array}{l}20 \\
(5.6 \%)\end{array}$ & 0 \\
\hline $\begin{array}{l}\text { Feeling } \\
\text { drowsy }\end{array}$ & $53.0 \%$ & $\begin{array}{l}27 \\
(7.6 \%)\end{array}$ & $\begin{array}{l}60 \\
(17 \%)\end{array}$ & $\begin{array}{l}52 \\
(14.7 \%)\end{array}$ & $\begin{array}{l}34 \\
(9.6 \%)\end{array}$ & $\begin{array}{l}15 \\
(4.2 \%)\end{array}$ & 2 \\
\hline $\begin{array}{l}\text { Problems with } \\
\text { sexual } \\
\text { interest or } \\
\text { activity }\end{array}$ & $51.8 \%$ & $\begin{array}{l}21 \\
(6 \%)\end{array}$ & $\begin{array}{l}32 \\
(9.1 \%)\end{array}$ & $\begin{array}{l}35 \\
(10 \%)\end{array}$ & $\begin{array}{l}34 \\
(9.7 \%)\end{array}$ & $\begin{array}{l}62 \\
(17.7 \%)\end{array}$ & 4 \\
\hline Diarrhoea & $51.3 \%$ & $\begin{array}{l}42 \\
(11.9 \%)\end{array}$ & $\begin{array}{l}42 \\
(11.9 \%)\end{array}$ & $\begin{array}{l}30 \\
(8.5 \%)\end{array}$ & $\begin{array}{l}31 \\
(8.8 \%)\end{array}$ & $\begin{array}{l}37 \\
(10.5 \%)\end{array}$ & 2 \\
\hline Pain & $42.6 \%$ & $\begin{array}{l}17 \\
(4.8 \%) \\
\end{array}$ & $\begin{array}{l}44 \\
(12.5 \%)\end{array}$ & $\begin{array}{l}44 \\
(12.5 \%)\end{array}$ & $\begin{array}{l}34 \\
(9.7 \%)\end{array}$ & $\begin{array}{l}11 \\
(3.1 \%)\end{array}$ & 3 \\
\hline Cough & $42.3 \%$ & $\begin{array}{l}36 \\
(10.3 \%) \\
\end{array}$ & $\begin{array}{l}45 \\
(12.8 \%)\end{array}$ & $\begin{array}{l}32 \\
(9.1 \%) \\
\end{array}$ & $\begin{array}{l}34 \\
(6.8 \%)\end{array}$ & $\begin{array}{l}13 \\
(3.7 \%)\end{array}$ & 4 \\
\hline $\begin{array}{l}\text { Feeling } \\
\text { bloated }\end{array}$ & $42.3 \%$ & $\begin{array}{l}24 \\
(6.9 \%)\end{array}$ & $\begin{array}{l}34 \\
(9.7 \%)\end{array}$ & $\begin{array}{l}29 \\
(8.3 \%)\end{array}$ & $\begin{array}{l}32 \\
(9.1 \%)\end{array}$ & $\begin{array}{l}31 \\
(8.9 \%)\end{array}$ & 5 \\
\hline Sweats & $40.3 \%$ & $\begin{array}{l}28 \\
(8.1 \%)\end{array}$ & $\begin{array}{l}41 \\
(11.8 \%)\end{array}$ & $\begin{array}{l}22 \\
(6.4 \%)\end{array}$ & $\begin{array}{l}32 \\
(9.2 \%)\end{array}$ & $\begin{array}{l}20 \\
(5.8 \%)\end{array}$ & 9 \\
\hline $\begin{array}{l}\text { Numbness/ } \\
\text { tingling in } \\
\text { hands/feet }\end{array}$ & $38.9 \%$ & $\begin{array}{l}30 \\
(8.5 \%)\end{array}$ & $\begin{array}{l}41 \\
(11.6 \%)\end{array}$ & $\begin{array}{l}29 \\
(8.2 \%)\end{array}$ & $\begin{array}{l}21 \\
(6 \%)\end{array}$ & $\begin{array}{l}17 \\
(4.8 \%)\end{array}$ & 3 \\
\hline $\begin{array}{l}\text { Changes in } \\
\text { skin }\end{array}$ & $38.6 \%$ & $\begin{array}{l}25 \\
(7.1 \%)\end{array}$ & $\begin{array}{l}33 \\
(9.4 \%)\end{array}$ & $\begin{array}{l}27 \\
(7.7 \%)\end{array}$ & $\begin{array}{l}24 \\
(6.9 \%)\end{array}$ & $\begin{array}{l}28 \\
(8.0 \%)\end{array}$ & 5 \\
\hline Dry mouth & $37.5 \%$ & $\begin{array}{l}35 \\
(10 \%)\end{array}$ & $\begin{array}{l}44 \\
(12.6 \%) \\
\end{array}$ & $\begin{array}{l}20 \\
(5.7 \%)\end{array}$ & $\begin{array}{l}19 \\
(5.4 \%)\end{array}$ & $\begin{array}{l}15 \\
(4.3 \%)\end{array}$ & 5 \\
\hline Itching & $35.8 \%$ & $\begin{array}{l}28 \\
(8.0 \%)\end{array}$ & $\begin{array}{l}36 \\
(10.2 \%)\end{array}$ & $\begin{array}{l}25 \\
(7.1 \%)\end{array}$ & $\begin{array}{l}22 \\
(6.3 \%)\end{array}$ & $\begin{array}{l}16 \\
(4.5 \%)\end{array}$ & 3 \\
\hline $\begin{array}{l}\text { "I don't look } \\
\text { like myself" }\end{array}$ & $32.1 \%$ & $\begin{array}{l}20 \\
(5.6 \%)\end{array}$ & $\begin{array}{l}20 \\
(5.6 \%)\end{array}$ & $\begin{array}{l}21 \\
(5.9 \%)\end{array}$ & $\begin{array}{l}15 \\
(4.2 \%)\end{array}$ & $\begin{array}{l}38 \\
(10.7 \%)\end{array}$ & 8 \\
\hline $\begin{array}{l}\text { Shortness of } \\
\text { breath }\end{array}$ & $31.0 \%$ & $\begin{array}{l}31 \\
(8.9 \%)\end{array}$ & $\begin{array}{l}22 \\
(6.3 \%)\end{array}$ & $\begin{array}{l}26 \\
(7.4 \%)\end{array}$ & $\begin{array}{l}20 \\
(5.7 \%)\end{array}$ & $\begin{array}{l}11 \\
(3.2 \%)\end{array}$ & 6 \\
\hline
\end{tabular}




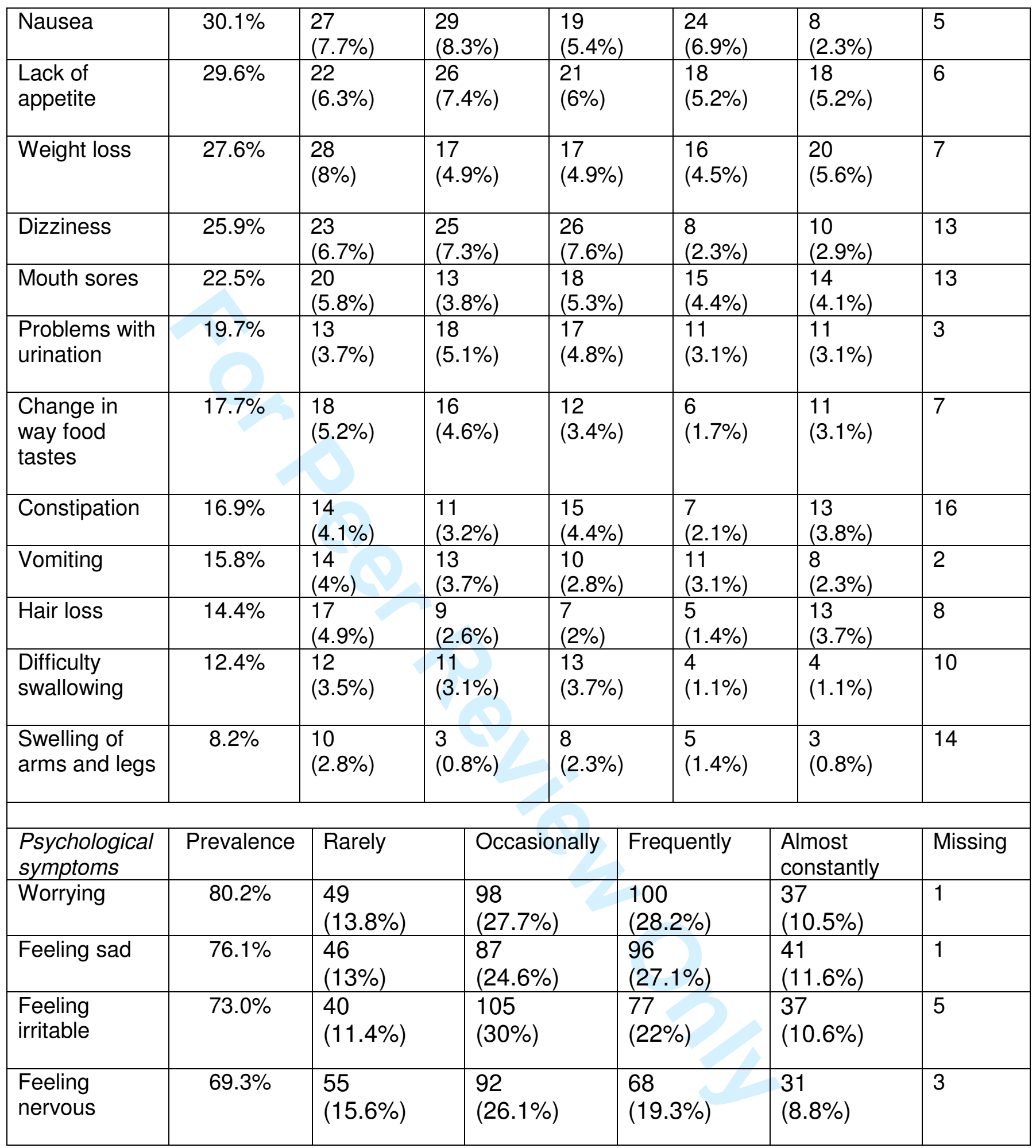




\section{Figure 1}

Key themes: qualitative barriers and facilitators to achieving personal goals and envisaging a future

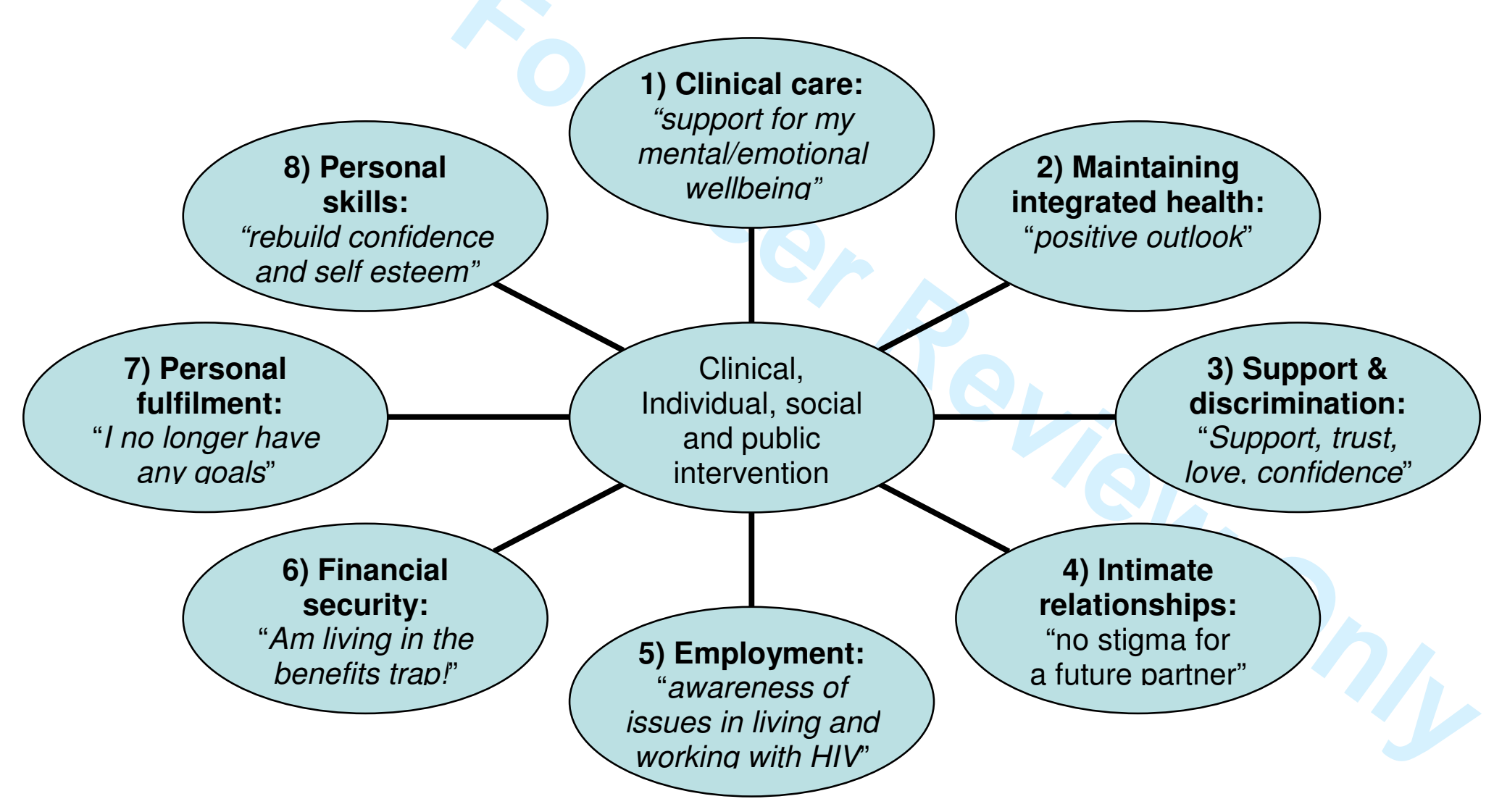

